\title{
Evaluation of Serum S100A8/S100A9 Levels in Patients with Autoimmune Thyroid Diseases
}

\author{
Hakan Korkmaz ${ }^{1}$, Suzan Tabur ${ }^{2}$, Esen Savaş3 ${ }^{3}$ Mesut Özkaya ${ }^{2}$, Şefika Nur Aksoy ${ }^{4}$, Nurten Aksoy ${ }^{5}$, Ersin Akarsu² \\ ${ }^{1}$ Department of Endocrinology and Metabolic Disease, Edirne State Hospital, Edirne, Turkey \\ ${ }^{2}$ Division of Endocrinology, Department of Internal Medicine, Gaziantep University School of Medicine, Gaziantep, Turkey \\ ${ }^{3}$ Department of Internal Medicine, Gaziantep University School of Medicine, Gaziantep, Turkey \\ ${ }^{4}$ Department of Clinical Biochemistry, Gaziantep University School of Medicine, Gaziantep, Turkey \\ ${ }^{5}$ Department of Clinical Biochemistry, Harran University School of Medicine, Şanlıurfa, Turkey
}

Background: The correlation of S100A8/S100A9 with various inflammatory conditions, including autoimmune diseases have been reported. There is no study investigating the levels of S100A8/S100A9 in autoimmune thyroid diseases (AITD)

Aims: We aimed to evaluate the level of serum S100A8/ S100A9 in AITD.

Study Design: Case control study.

Methods: Fifty patients with AITD (25 Hashimoto's thyroiditis (HT) and 25 Graves' disease (GD)) were included in the study. Twenty seven healthy subjects participated as a control group. Blood samples were obtained in the 3 months after the initiation of medical treatment. Serum levels of total antioxidant status (TAS), total oxidative status (TOS), total free sulfhy- dryl (SH), lipid hydroperoxide (LOOH) and S100A8/ S100A9 were analyzed.

Results: The patients with AITD had significantly higher S100A8/S100A9, OSI, LOOH and TOS levels than the healthy control group. There was no significant difference between GD and HT patients in terms of S100A8/S100A9, TOS and OSI levels. S100A8/ S100A9 level was positively correlated with $\mathrm{LOOH}$, TOS and OSI levels but negatively correlated with -SH level in the patients with AITD.

Conclusion: Serum S100A8/S100A9 levels were increased in patients with AITD and positively correlated with $\mathrm{LOOH}$, TOS and OSI whereas negatively correlated with SH.

Keywords: Autoimmune thyroid disease, oxidative status, S100A8/S100A9
Graves' disease (GD) and Hashimoto's thyroiditis (HT), considered two separate entities of the same disease, are the most common T-cell mediated organ-specific autoimmune thyroid diseases (AITD) (1).

Autoimmune thyroid diseases are characterized by a condition of increased oxidative stress. Increased oxidative stress is known to break down the immunological tolerance, leading to the proapoptotic effect and an inflammation of the thyroid gland (1-4).

The S100A8/S100A9 heterodimer, also known as calprotectin, is a member of the $\mathrm{S} 100$ protein family, which participates in inflammatory reactions. S100A8 and S100A9, both of which are separate proteins, form a heterocomplex to create the structure of calprotectin. These proteins comprise $45 \%$ of the total proteins in the cytosol of neutrophils, and they are expressed in neutrophils, monocytes, and dendritic cells $(5,6)$. Additionally, these proteins are released by the granulocytes and increase the release of proinflammatory cytokines by tolllike receptor 4 (TLR) signals (7).

In autoimmune diseases, such as ankylosing spondylitis, rheumatoid arthritis, inflammatory bowel diseases, systemic lupus erythematosus and dermatomyositis, it has been shown to increase serum levels of S100A8/S100A9 (8-10). In rheumatoid arthritis, it increases during the acute phase of the

This study has been presented at the $37^{\text {th }}$ Turkey Endocrinology and Metabolism Diseases Congress, 2015, Antalya, Turkey.

Address for Correspondence: Dr. Hakan Korkmaz, Department of Endocrinology and Metabolic Disease, Edirne State Hospital, Edirne, Turkey

Phone: +905059303322 e-mail: drhkorkmaz@yahoo.com.tr

Received: 16 July $2015 \quad$ Accepted: 19 April 2016 •DOI: 10.5152/balkanmedj.2016.15881

Available at www.balkanmedicaljournal.org

Korkmaz H, Tabur S, Savaş E, Özkaya M, Aksoy ŞN, Aksoy N, et al. Evaluation of serum S100A8/S100A9 levels in patients with autoimmune thyroid diseases.

Balkan Med J 2016;33:547-51 
disease, decreases after treatment, and is more sensitive than the hepatic-originated classic acute phase proteins (11-12). In AITD, which is also associated with inflammation, serum S100A8/S100A9 levels have not yet been determined.

We aimed to investigate serum S100A8/S100A9 levels in AITD in this study.

\section{MATERIALS AND METHODS}

An approval from local ethics committee was provided prior to the study. The study was initiated upon obtaining an informed consent from all subjects.

A total of 50 patients with AITD (25 patients with GD and 25 patients with HT) and 27 healthy controls were enrolled in the study (Table 1).

Thyroid ultrasonography was performed regardless of laboratory results in all patients (LOGIQ p6, GE Healthcare; Wauwatosa, USA). Thyroid function tests (free triiodothyronine (T3), free thyroxine (T4), high thyroid stimulating hormone (TSH)), anti-thyroid peroxidase (anti-TPO) antibody, antithyroid thyroglobulin (anti-TG) antibody were measured in all patients with AITD. Besides, thyroid stimulating hormone receptor antibody level and thyroid scintigraphy were evaluated in patients with GD. The medical history of the patients was recorded. Methimazole therapy was started for patients with GD and Levothyroxine therapy for patients with HT. Thyroid hormone levels of the cases were followed monthly. Serum samples were obtained during in euthyroid period in the third month of treatment.

TABLE 1. Demographic, clinical and laboratory parameters of HT, $\mathrm{GD}$ and $\mathrm{HC}$ groups

\begin{tabular}{|c|c|c|c|c|}
\hline & $\mathrm{HC}$ & GD & $\mathrm{HT}$ & $\mathrm{p}$ \\
\hline Age (year) & $43.92 \pm 12.78$ & $44.00 \pm 14.36$ & $41.44 \pm 9.53$ & 0.811 \\
\hline Gender (F/M) & $16 / 9$ & $17 / 8$ & $16 / 11$ & 0.806 \\
\hline BMI $\left(\mathrm{kg} / \mathrm{m}^{2}\right)$ & $25.78 \pm 2.01$ & $25.59 \pm 3.06$ & $26.64 \pm 2.16$ & 0.375 \\
\hline $\mathrm{FBG}(\mathrm{mg} / \mathrm{dL})$ & $88.92 \pm 8.15$ & $87.72 \pm 6.47$ & $86.96 \pm 6.47$ & 0.760 \\
\hline Total-C (mg/dL) & $173.48 \pm 28.64$ & $175.00 \pm 30.44$ & $179.04 \pm 30.53$ & 0.889 \\
\hline HDL-C (mg/dL) & $46.74 \pm 6.34$ & $47.92 \pm 6.71$ & $47.68 \pm 6.59$ & 0.558 \\
\hline LDL-C (mg/dL) & $105.25 \pm 25.30$ & $112.44 \pm 22.64$ & $116.04 \pm 29.26$ & 0.354 \\
\hline TG (mg/dL) & $137.85 \pm 46.26$ & $130.00 \pm 29.32$ & $129.80 \pm 26.94$ & 0.624 \\
\hline Free T3(pg/mL) & $2.69 \pm 0.48$ & $2.54 \pm 0.38$ & $2.82 \pm 0.52$ & 0.075 \\
\hline Free T4 (ng/dL) & $1.06 \pm 0.14$ & $1.14 \pm 0.23$ & $1.08 \pm 0.17$ & 0.189 \\
\hline TSH (uIU/mL) & $2.29 \pm 0.59$ & $2.15 \pm 0.52$ & $2.05 \pm 0.99$ & 0.541 \\
\hline
\end{tabular}

Data were expressed as mean \pm SD.

$\mathrm{p}<0.005$ was regarded as statistically significant.

BMI: Body Mass Index; FBG: fasting blood glucose; HDL-C: high density lipoprotein cholesterol; LDL-C: low density lipoprotein cholesterol; TG: triglyceride; T3: triiodothyronine; T4: tetraiodothyronine; TSH: thyroid stimulating hormone; GD: Graves' disease; HT: Hashimoto's thyroiditis; HC: healthy control
The exclusion criteria were: patients with inflammatory diseases, infectious diseases, cardiovascular diseases, liver diseases, malignancies, neurological diseases, obesity, diabetes mellitus, renal failure, and metabolic syndrome. Patients from both study and control groups on antioxidant treatments and smokers were excluded.

\section{Measurements}

All demographic data of the participants were recorded. Blood samples were obtained from all subjects following at least eight hour fasting period and serum samples were stored at $-80^{\circ} \mathrm{C}$. The biochemical parameters were measured in all subjects.

The electrochemiluminescence method was used to measure thyroid function tests, fasting plasma glucose (FPG), total cholesterol (Total-C), low density lipoprotein-cholesterol (LDL-C), high density lipoprotein-cholesterol (HDL-C), triglyceride (Cobas Integra 800 model auto-analyzer, Roche Diagnostics; Mannheim, Germany).

Serum S100A8/S100A9 level was determined using an enzyme-linked immunosorbent assay detection kit (Hycult biotec, HK325, Human Calprotectin ELISA kit, North Brabant, NLD).

Serum total oxidative and antioxidant status (TAS) levels were determined using a novel automated measurement method $(13,14)$. Percent ratio of TOS to TAS level was accepted as oxidative stress index [OSI (Arbitrary Unit) $=$ TOS $(\mathrm{mmol}$ $\mathrm{H}_{2} \mathrm{O}_{2}$ Equiv./l) / TAS (mmol Trolox Equiv./L) X100] $(15,16)$. Serum lipid hydroperoxide (LOOH) levels were measured with the ferrous ion oxidation-xylenol orange assay (15). Serum levels of free sulfhydryl (-SH) were determined using the method of Elman (17).

\section{Statistical analysis}

Power analysis was used to determine the sample (power $=0.80, \alpha=0.05, \mathrm{G}$ power 3.0; Dusseldorf, Germany). Continuous variables for normality were analyzed using the Shapiro-Wilk test. For normally distributed variables (S100A8/ S100A9, TAS, TOS, OSI, LOOH, -SH), 3 groups (GD, HT, and healthy control) were compared by using one-way analysis of variance (ANOVA) test, and 2 independent groups were compared using Student's t-test. For non-normally distributed variables (Total-C, BMI, HDL-C, triglyceride, LDL-C, free T3, free T4, FPG, TSH), 3 groups (GD, HT, and healthy control) were compared by using Kruskall Wallis test, and the comparison of 2 groups was performed by using Bonferroni corrected-Mann-Whitney $\mathrm{U}$ test. The associations between parameters were defined by Spearman correlation analysis. The variables affecting the S100A8/S100A9 was determined by multiple linear regression analysis. SPSS 15.0 program was used for the analysis data (SPSS Inc.; Chicago, IL, USA). 


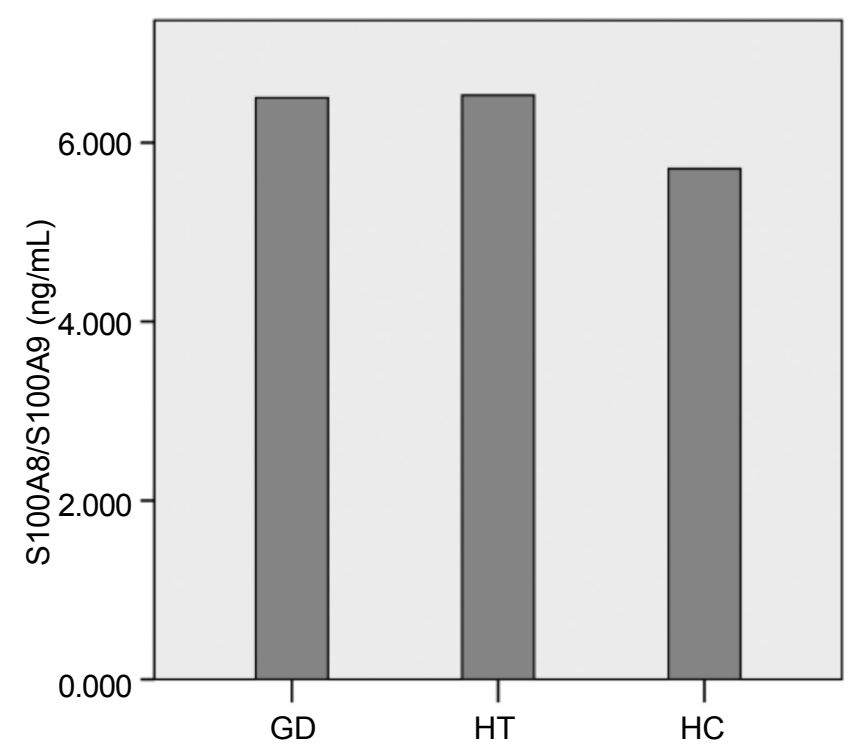

FIG. 1. Serum S100A8/S100A9 levels of the groups

Data in which non-parametric tests were used. Graves' disease, GD; Hashimoto's thyroiditis, HT; healthy control, HC. GD versus HC: $p<0.001, H T$ versus $H C$ : $p<0.001$

TABLE 2. Serum levels of S100A8/S100A9 and oxidant and antioxidant parameters in $\mathrm{HT}$, GD and $\mathrm{HC}$ groups

\begin{tabular}{lcccc}
\hline & $\mathrm{HC}$ & $\mathrm{GD}$ & $\mathrm{HT}$ & $\mathrm{P}$ \\
\hline TAS (mmol Trolox Equiv./L $)$ & $1.25 \pm 0.20$ & $1.33 \pm 0.36$ & $1.22 \pm 0.27^{\mathrm{b}}$ & 0.628 \\
TOS ( $\mu \mathrm{mol} \mathrm{H}_{2} \mathrm{O}_{2}$ Equiv./L) & $14.34 \pm 6.92$ & $24.82 \pm 8.60^{\mathrm{a}}$ & $25.19 \pm 19.15^{\mathrm{b}}$ & $<0.001$ \\
OSI (arbitrary unit) & $1.12 \pm 0.64$ & $2.14 \pm 1.13^{\mathrm{a}}$ & $2.24 \pm 1.51^{\mathrm{b}}$ & $<0.001$ \\
LOOH $(\mu \mathrm{mol} / \mathrm{L})$ & $5.98 \pm 3.08$ & $11.30 \pm 4.88^{\mathrm{a}}$ & $13.11 \pm 5.07^{\mathrm{b}, \mathrm{c}}<0.001$ \\
-SH (mmol/L) & $0.45 \pm 0.12$ & $0.16 \pm 0.05^{\mathrm{a}}$ & $0.18 \pm 0.09^{\mathrm{b}}$ & $<0.001$ \\
\hline
\end{tabular}

Data in which non-parametric tests were used and expressed as mean $\pm \mathrm{SD}$. ap $<0.001 \mathrm{GD}$ versus $\mathrm{HC}, \mathrm{bp}<0.001 \mathrm{HT}$ versus $\mathrm{HC}, \mathrm{cp}<0.01 \mathrm{GD}$ versus HT.

TAS: total antioxidant status; TOS: total oxidant status; OSI: Oxidative Stress Index; LOOH: lipid hydroperoxide; -SH: total free sulfhydryl; GD: Graves' disease; HT: Hashimoto's thyroiditis; HC: healthy control

\section{RESULTS}

The groups were similar in terms of age, gender, BMI, FPG, LDL-C, HDL-C, free T3, free T4 and TSH levels (Table 1). The patients with GD and HT had significantly lower SH levels and, had significantly higher S100A8/S100A9, OSI, LOOH and TOS levels than the healthy control group. There was no significant difference between GD and HT patients in terms of S100A8/ S100A9, SH, TOS and OSI levels. In the HT patients had significantly higher $\mathrm{LOOH}$ levels than the GD patients. There was no difference in terms of TAS levels (Figure 1, Table 2).

S100A8/S100A9 level was positively correlated with LOOH, TOS and OSI levels whereas negatively correlated with -SH level in AITD patients (Table 3). Multivariate re-
TABLE 3. Correlations between prolidase and oxidant and antioxidant parameters

\begin{tabular}{lccccc}
\hline & TOS & OSI & LOOH & -SH & TAS \\
\hline S100A8/S100A9 & & & & & \\
$\mathrm{R}$ & 0.429 & 0.423 & 0.392 & -0.360 & -0.020 \\
$\mathrm{P}$ & $<0.001$ & $<0.001$ & $<0.001$ & 0.001 & 0.861 \\
\hline TOS & & & & \\
$\mathrm{R}$ & 0.948 & 0.724 & -0.693 & -0.061 \\
$\mathrm{P}$ & $<0.001$ & $<0.001$ & $<0.001$ & 0.596 \\
\hline OSI & & & & \\
$\mathrm{R}$ & & 0.664 & -0.587 & -0.339 \\
$\mathrm{P}$ & & $<0.001$ & $<0.001$ & 0.002 \\
\hline LOOH & & & & \\
$\mathrm{R}$ & & & -0.616 & -0.072 \\
$\mathrm{P}$ & & & $<0.001$ & 0.532 \\
\hline -SH & & & & \\
$\mathrm{R}$ & & & & 0.201 \\
$\mathrm{P}$ & & & & & 0.080 \\
\hline
\end{tabular}

TAS: total antioxidant status; TOS: total oxidant status; OSI: Oxidative Stress Index; LOOH: lipid hydroperoxide; -SH: total free sulfhydryl

TABLE 4. Multiple linear regression analysis between S100A8/S100A9 and $\mathrm{LOOH}$ and OSI

\begin{tabular}{lcc}
\hline & $\beta$ coefficients & $\mathrm{P}$ \\
\hline OSI (arbitrary unit) & 0.262 & 0.045 \\
LOOH $(\mu \mathrm{mol} / \mathrm{L})$ & 0.290 & 0.027 \\
\hline
\end{tabular}

OSI: Oxidative Stress Index; LOOH: lipid hydroperoxide

gression analysis revealed that the levels of OSI and $\mathrm{LOOH}$ were independent variables predicting the S100A8/S100A9 levels (R: $0.495, R^{2}: 0.245$; Table 4). There was no correlation between S100A8/S100A9 and TAS, anti-TPO, anti-TG levels $(\mathrm{r}=0.201, \mathrm{p}=0.165 ; \mathrm{r}=0.039, \mathrm{p}=0.789$ and $\mathrm{r}=0.129, \mathrm{p}=0.379)$.

\section{DISCUSSION}

The results of this study revealed an elevated serum S100A8/ S100A9 levels in the AITD, and a positive correlation with OSI, LOOH and TOS which are described as oxidative stress markers. Our study accounts for the first in the literature investigating the S100A8/S100A9 serum levels in the AITD, which is associated with increased inflammation.

Hydrogen peroxide $\left(\mathrm{H}_{2} \mathrm{O}_{2}\right)$, a variety of reactive oxygen species (ROS), is used for the thyroid hormone synthesis. $\mathrm{H}_{2} \mathrm{O}_{2}$ is scavenged by antioxidant mechanisms and/or thyroid hormone synthesis. However, the T lymphocytes infiltrating the thyroid gland result in the overexpression of ROS, leading to increased oxidative stress in AITD (2). Free radicals increase, and antioxi- 
dant activity decreases, in cases of hypo- and hyperthyroidism in AITD (18). However, in other studies, different results have been obtained. Erdamar et al. (19) have shown that free radicals and antioxidants return to normal levels in GD patients after they become euthyroid with one month of anti-thyroid treatment. Komosinska-Vassev et al. (20) have detected antioxidant mechanism recovery after the treatment of GD patients. However, Baser et al. have reported TAS levels were lower and TOS levels were higher in euthyroid AITD cases, compared to those in healthy subjects. In addition, they found that there was a negative correlation between serum TAS levels and anti-tpo and anti-tg, a negative correlation between TOS levels and anti-tg (21). The oxidant markers evaluated in this study included TOS, OSI, LOOH, and the antioxidant markers included -SH and TAS. The TOS, $\mathrm{LOOH}$, and OSI levels were found higher and the $-\mathrm{SH}$ levels were found lower in GD and HT groups, compared to the healthy control group (Table 2). We found no correlation between oxidative stress markers and anti-tpo and anti-tg levels.

Oxidative stress is known to increase the inflammation in AITD. However, the mechanism of this process remains unknown. The S100A8/A9 heterodimer participates in inflammatory processes. S100A8/S100A9 serum levels are reported to increase in various inflammatory autoimmune diseases $(10,22-25)$. In this study, S100A8/S100A9 serum levels were evaluated, since AITD is an inflammatory autoimmune disease. The results of the present study (Table 3 ) suggest that the increased oxidative stress in AITD may increase the S100A8/ S100A9-mediated inflammatory processes.

Some level of oxidative load is needed for thyroid function and proliferation. In AITD, however, increased oxidative stress caused by TH1-induced ROS production results in cellular and tissue damage. The S100A8/S100A9 heterodimer is highly sensitive to oxidation and has a major role in the scavenging of the oxidants and the preservation of tissue components and proteins $(6,26)$. Our data indicated that the increase in the $\mathrm{S} 100 \mathrm{~A} 8 / \mathrm{S} 100 \mathrm{~A} 9$ serum levels act as protective mechanism in parallel with the increase in oxidative stress. However, it is reported that the release of S100A9 from the oxidation in the S100A8/S100A9 heterodimer increase the secretion of nuclear factor kappa B and inflammatory cytokines upon TLR4 stimulation. Other authors maintain that S100A8 is the main active component of the S100A8/S100A9 heterodimer. Nevertheless, this issue remains debatable $(6,27,28)$.

In conclusion, the increased levels of S100A8/S100A9 suggest that these inflammatory markers may have a role in the pathogenesis of AITD.

Ethics Committee Approval: Ethics committee approval was received for this study from the ethics committee of Gaziantep University School of Medicine.
Informed Consent: Written informed consent was obtained from patients who participated in this study.

Peer-review: Externally peer-reviewed.

Author contributions: Concept - H.K., S.T.; Design - H.K., S.T.; Supervision - H.K., S.T., M.Ö.; Resource - H.K., S.T., E.S.; Materials - H.K., S.T., S.N.A, N.A.; Data Collection and/or Processing - H.K., S.T.; Analysis and/or Interpretation - H.K., E.A.; Literature Search - H.K., S.T., E.S.; Writing - H.K., S.T., S.N.A.; Critical Reviews H.K., E.S., M.Ö., E.A.

Conflict of Interest: No conflict of interest was declared by the authors.

Financial Disclosure: The authors declared that this study has received no financial support.

\section{REFERENCES}

1. Antonelli A, Ferrari SM, Corrado A, Di Domenicantonio A, Fallahi P. Autoimmune thyroid disorders. Autoimmun Rev 2015;14:174-180. [CrossRef]

2. Zarković M. The role of oxidative stress on the pathogenesis of graves' disease. J Thyroid Res 2012;2012:302537 [CrossRef]

3. Marcocci C, Leo M, Altea MA. Oxidative stress in graves' disease. Eur Thyroid J 2012;1:80-7. [CrossRef]

4. Rostami R, Aghasi MR, Mohammadi A, Nourooz-Zadeh J. Enhanced oxidative stress in Hashimoto's thyroiditis: interrelationships to biomarkers of thyroid function. Clin Biochem 2013;46:308-12. [CrossRef]

5. Stríz I, Trebichavský I. Calprotectin- a pleiotropic molecule in acute and chronic inflammation. Physiol Res 2004;53:245-53.

6. Schiopu A, Cotoi OS. S100A8 and S100A9: DAMPs at the crossroads between innate immunity, traditional risk factors, and cardiovascular disease. Mediators Inflamm 2013;2013:828354. [CrossRef]

7. Ehrchen JM, Sunderkötter C, Foell D, Vogl T, Roth J. The endogenous Toll-like receptor 4 agonist S100A8/S100A9 (calprotectin) as innate amplifier of infection, autoimmunity, and cancer. $J$ Leukoc Biol 2009;86:557-66. [CrossRef]

8. van Bon L, Cossu M, Loof A, Gohar F, Wittkowski H, Vonk M, et al. Proteomic analysis of plasma identifies the Toll-like receptor agonists S100A8/A9 as a novel possible marker for systemic sclerosis phenotype. Ann Rheum Dis 2014;73:1585-9. [CrossRef]

9. Lin JF, Chen JM, Zuo JH, Yu A, Xiao ZJ, Deng FH, et al. Meta-analysis: fecal calprotectin for assessment of inflammatory bowel disease activity. Inflamm Bowel Dis 2014;20:1407-15. [CrossRef]

10. García-Arias M, Pascual-Salcedo D, Ramiro S, Ueberschlag ME, Jermann TM, Cara C, et al. Calprotectin in rheumatoid arthritis : association with disease activity in a cross-sectional and a longitudinal cohort. Mol Diagn Ther 2013;17:49-56. [CrossRef] 
11. Andrés Cerezo L, Mann H, Pecha O, Pleštilová L, Pavelka K, Vencovský J, et al. Decreases in serum levels of S100A8/9 (calprotectin) correlate with improvements in total swollen joint count in patients with recent-onset rheumatoid arthritis. Arthritis Res Ther 2011;13:R122. [CrossRef]

12. Hurnakova J, Zavada J, Hanova P, Hulejova H, Klein M, Mann $\mathrm{H}$, et al. Serum calprotectin (S100A8/9): an independent predictor of ultrasound synovitis in patients with rheumatoid arthritis. Arthritis Res Ther 2015;17:252 [CrossRef]

13. Erel O. A novel automated method to measure total antioxidant response against potent free radical reactions. Clin Biochem 2004;37:112-9. [CrossRef]

14. Erel O. A new automated colorimetric method for measuring total oxidant status. Clin Biochem 2005;38:1103-11. [CrossRef]

15. Arab K, Steghens JP. Plasma lipid hydroperoxides measurement by an automated xylenol orange method. Anal Biochem 2004;325:158-63. [CrossRef]

16. Aycicek A, Erel O, Kocyigit A. Increased oxidative stress in infants exposed to passive smoking. Eur J Pediatr 2005; 164:7758. [CrossRef]

17. Ellman GL. Tissue sulfhydryl groups. Arch Biochem Biophys 1959;82:70-7. [CrossRef]

18. Lassoued S, Mseddi M, Mnif F, Abid M, Guermazi F, Masmoudi $\mathrm{H}$, et al. A comparative study of the oxidative profile in Graves' disease, Hashimoto's thyroiditis, and papillary thyroid cancer. Biol Trace Elem Res 2010;138:107-15. [CrossRef]

19. Erdamar H, Demirci H, Yaman H, Erbil MK, Yakar T, Sancak B, et al. The effect of hypothyroidism, hyperthyroidism, and their treatment on parameters of oxidative stress and antioxidant status. Clin Chem Lab Med 2008;46:1004-10. [CrossRef]

20. Komosinska-Vassev K, Olczyk K, Kucharz EJ, Marcisz C, Winsz-Szczotka K, Kotulska A. Free radical activity and antioxidant defense mechanisms in patients with hyperthyroi- dism due to Graves' disease during therapy. Clin Chim Acta 2000;300:107-17. [CrossRef]

21. Baser H, Can U, Baser S, Yerlikaya FH, Aslan U, Hidayetoglu BT. Assesment of oxidative status and its association with thyroid autoantibodies in patients with euthyroid autoimmune thyroiditis. Endocrine 2015;48:916-23. [CrossRef]

22. Hansson C, Eriksson C, Alenius GM. S100A8/S100A9: a potential marker of inflammation in patients with psoriatic arthritis. $J$ Immunol Res 2014;2014:696415. [CrossRef]

23. Oktayoglu P, Bozkurt M, Mete N, Caglayan M, Em S, Nas K. Elevated serum levels of calprotectin (myeloid-related protein 8/14) in patients with ankylosing spondylitis and its association with disease activity and quality of life. $J$ Investig Med 2014;62:880-4. [CrossRef]

24. Tydén H, Lood C, Gullstrand B, Jönsen A, Nived O, Sturfelt $\mathrm{G}$, et al. Increased serum levels of S100A8/A9 and S100A12 are associated with cardiovascular disease in patients with inactive systemic lupus erythematosus. Rheumatology (Oxford) 2013;52:2048-55. [CrossRef]

25. van Bon L, Cossu M, Loof A, Gohar F, Wittkowski H, Vonk M, et al. Proteomic analysis of plasma identifies the Toll-like receptor agonists S100A8/A9 as a novel possible marker for systemic sclerosis phenotype. Ann Rheum Dis 2014;73:1585-9. [CrossRef]

26. Poncin S, Van Eeckoudt S, Humblet K, Colin IM, Gérard AC. Oxidative stress: a required ondition for thyroid cell proliferation. Am J Pathol 2010;176:1355-63. [CrossRef]

27. Lim SY, Raftery MJ, Goyette J, Hsu K, Geczy CL. Oxidative modifications of $\mathrm{S} 100$ proteins: functional regulation by redox. J Leukoc Biol 2009;86:577-87. [CrossRef]

28. Ryckman C, Vandal K, Rouleau P, Talbot M, Tessier PA. Proinflammatory activities of S100: proteins S100A8, S100A9, and S100A8/A9 induce neutrophil chemotaxis and adhesion. $J$ Immunol 2003;170:3233-42. [CrossRef] 